\title{
Assessment of Heavy Metals in Drinking Water (Hand Dug Well) in Oye Ekiti, Nigeria
}

\author{
Fatoye, A. O. ${ }^{1}$, Gbadegesin, $\mathrm{KAJ}^{2}$ \\ ${ }^{1,2}$ Department of Science Technology, Federal Polytechnic Ado Ekiti, PMB 5351, Ado Ekiti, Ekiti State, Nigeria
}

\begin{abstract}
The purpose of study was to assess heavy metals $(\mathrm{Fe}, \mathrm{Cd}, \mathrm{Pb}, \mathrm{Zn}, \mathrm{Ni})$ in drinking water. Twenty samples were analysed using atomic absorption spectrophotometer. The result show that the average heavy metal levels in all water samples followed a descending order: $\mathrm{Zn}>\mathrm{Fe}>\mathrm{Pb}>\mathrm{Ni}>\mathrm{Cd}$. It was observed that heavy metals investigated exceeded the maximum permissible limit in drinking water as specified by regulatory bodies except cadmium which was below standard. Pollution index result confirmed significant pollution in $\mathrm{Pb}$, Ni and Fe.
\end{abstract}

Keywords: Heavy metals, Drinking water, permissible limit, pollution index

\section{Introduction}

The increasing consumption and exploitation of the earth's raw materials (fossil fuel and minerals) coupled with the exponential population growth over the past years have resulted in environmental degradation and build up of waste products of which metals is of great concern $(1,2)$.

The term "heavy metals" refers to any metallic element that has a relatively high density and is toxic or poisonous even at low concentration (3). "Heavy metals" is a general collective term, which applies to the group of metals and metalloids with atomic density greater than $4 \mathrm{~g} / \mathrm{cm} 3$, or 5 times or more, greater than water $(4,5,6,7,8,9)$. However, being a heavy metal has little to do with density but concerns chemical properties.

Heavy metals include lead $(\mathrm{Pb})$, cadmium $(\mathrm{Cd})$, zinc $(\mathrm{Zn})$, mercury $(\mathrm{Hg})$, arsenic (As), silver $(\mathrm{Ag})$ chromium $(\mathrm{Cr})$, copper $(\mathrm{Cu})$ iron $(\mathrm{Fe})$, and the platinum group elements. It is believed that the great majority of heavy metals act as a key components of essential enzyme systems or other proteins, e.g. . The haemoprotein hemoglobin which performs vital biochemical functions $(10,11)$. Zinc cadmium, lead etc are highly toxic for human bio-system even at very low levels of intake and they are usually present in plants because of the increasing industrialization and associated pollution at the biosphere, taken up from the soil, water, fertilizers, pesticides treatment and anthropogenic operations $(12,13)$. Factories and human social and agricultural activities have an effect on environmental pollution and the ecosystem. The corruption of the ecosystem has a negative effect on human health and on all living Organisms $(12,13,14)$.

Trace metals, among a wide range of contaminants, are consistently of health concern due to their toxicity potentials at very low concentrations, and tendency to bioaccumlate in tissues of living organisms over time (15). They gain entrance into human systems via contaminated drinking water, food and air. Once in the body, the bioavailable form of these metals can compete with, and displace essential minerals such as zinc, copper, magnesium and calcium; and interfere with organ system function (16).
Drinking water sources in these so-called developing countries are under increasing threat from contaminations by chemical, physical and microbial pollutants. Known sources (both naturally occurring and anthropogenic) of chemical contamination of water supplies include organic and inorganic substances from industrial effluents, municipal wastes, petroleum derived hydrocarbons, detergents, mining, agricultural pesticides and fertilizers $(17,18)$.

According to a recent report by WHO/UNICEF, about 780 million people in the developing world lack access to potable water due largely to microbiological and chemical contaminations (19). Drinking water sources in these socalled developing countries are under increasing threat from contaminations by chemical, physical and microbial pollutants. Known sources (both naturally occurring and anthropogenic) of chemical contamination of water supplies include organic and inorganic substances from industrial effluents, municipal wastes, petroleum derived hydrocarbons, detergents, mining, agricultural pesticides and fertilizers $(3,4)$.

Therefore, this research work was aimed at assessing the concentrations of $\mathrm{Fe}, \mathrm{Cd}, \mathrm{Pb}, \mathrm{Zn}$ and $\mathrm{Ni}$ in hand dug well drinking water sources. Also, to determine the heavy metal pollution indices as well as compare the observed concentrations with the water quality permissible limits specified by the regulatory bodies.

\section{Materials and Methods}

\section{A. Description of Study Area}

Oye Ekiti is a town and headquarters of Oye Local Government Area in Ekiti state, western Nigeria. It has a geographical coordinates of $7^{\circ} 8^{\prime} 00^{\prime \prime} \mathrm{N}$ and $5^{\circ} 33^{\prime} 00^{\prime \prime} \mathrm{E}$. The major occupation of the inhabitant is farming. Their major sources of water are underground and rivers.

\section{B. Sample Collection, Pre-Treatment and Chemical Analysis}

Twenty water samples were randomly collected within Oye Ekiti in Ekiti state. Samples were collected in 1L polyethylene container. The sample containers were washed with $20 \%$ analytical grade nitric acid and rigorously rinsed 


\section{International Journal of Science and Research (IJSR) \\ ISSN (Online): 2319-7064 \\ Index Copernicus Value (2013): 6.14 | Impact Factor (2014): 5.611}

with distilled deionized water. Prior to sampling, it was further rinsed with the actual sample. Collected samples were preserved by chemical adjustment of the $\mathrm{pH}<2$, by acidifying with 5 milliliters of analytical grade nitric acid. This reduces precipitation and sorption losses to the container walls. After which the samples were stored under ice on transit and then refrigerated after arriving at the laboratory at a temperature of $\left(4^{\circ} \mathrm{C}\right)$ prior to analysis. The water samples and reagent blank were digested using concentrated nitric acid (HNO3) for the determination of metal ions concentration and was further analysed using VGP 210 (Buck Scientific)atomic absorption spectrophotometer (AAS). Also, prior to metal ion analyses, calibration solutions of the target metal ions were prepared from standard stock by serial dilution. Quality assurance and control was performed according to the specified method of (20).

\section{Pollution Index (Pi)}

Pollution index $(\mathrm{Pi})$ is defined as the ratios of the concentration of individual parameter against the baseline standard. It provides information on the relative pollution contributed by individual samples. The critical value is 1.0 , values greater than 1.0 indicates significant degree of pollution while values less than 1.0 shows no pollution (21, 22). $\mathrm{Pi}$ is computed as:

\section{$\mathrm{P}_{\mathrm{i}}=$ Concentration}

Standard

\section{RESULTS AND DISCUSSIONS}

To assess the potability and safety of water for drinking purpose, the concentrations of heavy metals in the present study were compare with the regulatory bodies standard for drinking water quality.

Table 1: Concentration of heavy metals in drinking water (hand dug well).

\begin{tabular}{|c|c|c|c|c|c|}
\hline $\begin{array}{c}\text { Sample } \\
\text { Code }\end{array}$ & $\begin{array}{c}F e \\
(p p m)\end{array}$ & $\begin{array}{c}C d \\
(p p m)\end{array}$ & $\begin{array}{c}P b \\
(p p m)\end{array}$ & $\begin{array}{c}Z n \\
(p p m)\end{array}$ & $\begin{array}{c}N i \\
(p p m)\end{array}$ \\
\hline 1 & 0.45 & BDL & 0.31 & BDL & 0.08 \\
\hline 2 & 0.03 & 0.01 & 0.27 & BDL & BDL \\
\hline 3 & 3.08 & BDL & 0.30 & BDL & BDL \\
\hline 4 & BDL & 0.01 & 0.35 & BDL & BDL \\
\hline 5 & 0.71 & 0.01 & 0.17 & BDL & BDL \\
\hline 6 & 1.50 & 0.01 & 0.31 & BDL & BDL \\
\hline 7 & 0.05 & 0.01 & 0.35 & BDL & BDL \\
\hline 8 & BDL & BDL & 0.34 & BDL & BDL \\
\hline 9 & BDL & 0.01 & 0.27 & BDL & BDL \\
\hline 10 & BDL & BDL & 0.34 & BDL & BDL \\
\hline 11 & 0.08 & BDL & 0.45 & BDL & BDL \\
\hline 12 & 0.06 & BDL & 0.31 & BDL & BDL \\
\hline 13 & 0.01 & BDL & 0.20 & BDL & BDL \\
\hline 14 & BDL & 0.01 & 0.41 & BDL & BDL \\
\hline 15 & BDL & BDL & 0.10 & 1.04 & BDL \\
\hline 16 & 0.75 & BDL & 0.24 & 9.90 & BDL \\
\hline 17 & 0.25 & 0.01 & 0.27 & 0.06 & BDL \\
\hline 18 & 0.01 & 0.01 & 0.24 & 0.03 & BDL \\
\hline 19 & BDL & BDL & 0.32 & 0.03 & BDL \\
\hline 20 & 0.28 & 0.01 & 0.31 & 0.18 & BDL \\
\hline Average & 0.36 & 0.01 & 0.29 & 1.87 & 0.08 \\
\hline
\end{tabular}

$\mathrm{BDL}=$ Below Detection Level
Table 2: showing the regulatory body standard for drinking water

\begin{tabular}{|c|c|c|}
\hline ELEMENT & SON & WHO \\
\hline $\mathrm{Fe}$ & 0.30 & - \\
\hline $\mathrm{Cd}$ & 0.02 & 0.07 \\
\hline $\mathrm{Pb}$ & 0.01 & 0.01 \\
\hline $\mathrm{Zn}$ & 3.00 & - \\
\hline $\mathrm{Ni}$ & 0.02 & 0.07 \\
\hline
\end{tabular}

$\mathrm{SON}=$ Standard Organization of Nigeria

$\mathrm{WHO}=$ World Health Organization

Table 3: Pollution Index for the metal ions

\begin{tabular}{|c|c|}
\hline Parameter & Pollution Index \\
\hline $\mathrm{Fe}$ & 1.20 \\
\hline $\mathrm{Cd}$ & 0.50 \\
\hline $\mathrm{Pb}$ & 29.0 \\
\hline $\mathrm{Zn}$ & 0.62 \\
\hline $\mathrm{Ni}$ & 4.00 \\
\hline
\end{tabular}

The result as shown in table 1 indicate that all the heavy metals i.e $\mathrm{Fe}, \mathrm{Cd}, \mathrm{Pb}, \mathrm{Zn}$ and $\mathrm{Ni}$ assessed are above the regulatory body standard for drinking water.

The excessive concentration of Fe may be attributed to rocks and soil containing iron, which can dissolve into the water source. Even though iron poses no danger to health at levels found in drinking water, it may affect acceptability of drinking water by altering its appearance, taste, odour, stain clothing and appliances and promote the growth of iron bacteria in the water system (23).

$\mathrm{Pb}$ concentration is above the permissible level which could be associated with the corrosive water effects on household plumbing systems containing lead in pipes, solder, fittings or the service connections to homes. It can also be attributed to anthropogenic activities.

The concentration of $\mathrm{Ni}$ and $\mathrm{Cd}$ as shown in Table 1 were found relatively in low concentrations in all the samples.

The concentration of $\mathrm{Zn}$ as shown in Table 1 were found relatively in low concentrations in all the samples except sample 16 which may be attributed to household plumbing systems.

The pollution Index value is presented in Table 3 . The values obtained for iron, cadmium, lead, zinc and nickel in all the samples investigated revealed that some of the waters sources were polluted. Amongst the five metals, significant degree of pollution was seen in lead, iron and nickel. This confirms the results on trace metals above permissible limit $(\mathrm{Fe}, \mathrm{Pb}$ and $\mathrm{Ni}$ ), for the different water sources as discussed above.

\section{Conclusions and Recommendations}

The result show that the average heavy metal levels in all water samples followed a descending order: $\mathrm{Zn}>\mathrm{Fe}>\mathrm{Pb}>$ $\mathrm{Ni}>>\mathrm{Cd}$ in the observed water sample (Table 1) exceeded the maximum permissible limits in drinking water except $\mathrm{Cd}$ as specified by WHO and SON standards. Also, the pollution index result obtained confirmed significant pollution in lead, nickel and iron. It is therefore suggested 


\section{International Journal of Science and Research (IJSR) \\ ISSN (Online): 2319-7064}

Index Copernicus Value (2013): 6.14 | Impact Factor (2014): 5.611

and advised that the concern contaminated sources be subjected to further treatments that will reduce the concentration of these identified heavy metals which are capable of causing life threatening diseases to the consumers. General public are advised to test their drinking water sources periodically.

\section{References}

[1] Kabata-Pendias A. Trace elements in soil and plants(3rdedn.) CRC Press, Boca, Florida, P(413) (2001).

[2] Diagmanolin. Transfers of metals from soil to vegetables in an area near a smelter in Naming, China. Environ. Inter. 30(6), PP(785 - 791) (2004).

[3] Lenntech Water Treatment and Air Purification .Water Treatment, Published by Lenntech, Rotterdamseweg, Netherlands (2004). (WWW.excelwater. Com/thp/filters/Water-Purification.htm).

[4] Hutton M, and Symon C. The Quantities of Cadmium, Lead, Mercury and Arsenic Entering the U.K. Environment from Human Activities. Sci. Total Environ. 57:129-150(1986).

[5] Battarbee R, Anderson N, Appleby P, Flower RJ, Firtz $\mathrm{S}$, Haworth E, Higgit S, Jones V, Kresier A, Murno MA, Natkanski J, Oldfield F,Patrick ST, Richardson N, Rippey B, Stevenson AC. Lake Acidification in the united Kingdom , ENSIS, London(1998). http://WWW.geog.ucl.ac.uk/-spatrick/f_r_pubs.htm

[6] Niragu JO , Pacyna J. Quantitative Assessment of Worldwide Contamination of Air, Water and Soil by Trace Metals , Nature, 333:134-139(1988).

[7] Niragu JO. A global Assessment of Natural Sources of Atmospheric Trace Metals, Nature, 338:47-49(1989).

[8] Garbarino JR, Hayes H, Roth D, Antweider R, Brinto TI, Taylor H. Contaminants in the Mississippi River, U.S . Geological Survey Circular 1133, Virginia, U.S.A(1995). (WWW.Pubs.usgs.gov/circ/circ1133/)

[9] Hawkes JS. Heavy Metals , J. Chem. Educ.74(11):1374(1997).

[10]Hunt ,J.A Bioavailability of $\mathrm{Fe}, \mathrm{Zn}$ and other trace minerals for vegetation diets. Am. J. clin.Nutr., 78, PP(633-639) (2003).

[11] Chen, Z.S. Metal contamination of flooded soil, Rice plants and surface water in Asia, Ed. Adriano. Biochemistry of trace metals, Lewis Publishers Inc. P(125) (1992).

[12] Yagdik .Heavy metal contamination in soil and its effects in agriculture,J.Fac.Agric.,15, P(109-115) (2000).

[13] OnderS. Determination of heavy metal pollution in grass and soil. J .environ .Stud.,16(1), PP(145-154) (2007).

[14]Zheng,Y. Multivariategeostatistical analysis of heavy metals in top oils from Beijing chaina ,J.of soil sediments, 8, PP(51-58) (2008).

[15] Ikejimba, C. C and Sakpa, S. Comparative study of some heavy metals' concentrations in water and Tympanotonus fuscatus var radula samples of Egbokodo River, Warri, Nigeria. International journal of Modern Biological Research, 2, 7-15(2014).

[16] Wu, J.L., Zeng, H.A., Yu, H., Ma, L., Xu, L.S. and Qin, B.Q. Water and sediment quality in lakes along the middle and lower reaches of the Yangtze River, China.Water Resour. Manage, 12, 3601-3618(2012).

[17] Ergul, H. A., Varol, T., Ay, U. Investigation of heavy metal pollutants at various depths in the Gulf of Izmit. Marine Pollution Bulletin 73, 389-393(2013).

[18] Ndamitso, M. M., Idris S, Likita M. B., Tijani J. O., Ajai A. I. and Bala A. A. Physicochemical and Escherichia coli assessment of selected sachet water produced in some areas of Minna, Niger State, Nigeria. International Journal of Water Resources and Environmental Engineering, 5(3) 134-140(2013).

[19] WHO/UNICEF. Estimated data from WHO/UNICEF Joint Monitoring Programme (JMP) for Water Supply and Sanitation. Progress on Sanitation and DrinkingWater, 2012 Update.

[20]EPA. Sampling and analysis of waters, wastewaters, soils and wastes. Retrieved March 13, 2011,from http://www.epa.vic.gov.au/ /media/Publications/IWRG 701.pdf

[21] Akpoveta, O.V., Okoh B.E. and Osakwe, S.A. Quality assessment of borehole water used in the vicinities of Benin, Edo State and Agbor, Delta State of Nigeria. Current Research in Chemistry, 3: 62-69(2011).

[22] Umeobika, U.C., Ajiwe, V.I.E, Iloamaeke, M.I., Alisa, C.O. Physicochemical analysis of rain water collected from 10 selected areas in Awka South, Anambra State, Nigeria. International Journal of Science Innovations and Discoveries, 3(1), 56-73(2013).

[23] World Health Organization. Guideline for drinking water quality - 4th Edition(2011).

\section{Author Profile}

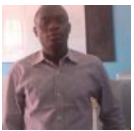

Fatoye Abiodun O. received HND, PGD and MTech( in view) degree in Applied / Industrial/ Analytical Chemistry from Federal Polytechnic Ado Ekiti and Federal University of Technology Akure in 1997 and 2013, respectively. During 1999-2011, he stayed in Kemeng Services Limited as Quality Assurance Officer. He is now with Federal Polytechnic Ado Ekiti, Nigeria.

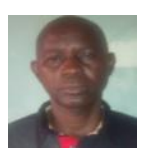

Gbadegesin, Karonwi Adedayo Joseph received BSc and MSc degree in Physics/Geophysics from University of Ibadan, Nigeria in 1990 and 2000 respectively. During 1991-2000, he stayed in The Polytechnic Ibadan. $\mathrm{He}$ is now with Federal Polytechnic Ado Ekiti, Nigeria. 